\title{
Providing Quality of Shredded Carrots during Storage by Treatment with Ozonated Water
}

\author{
Ingrida Augspole ${ }^{1}$, Tatjana Rakcejeva ${ }^{2}$, Lija Dukalska ${ }^{3}$, Liga Skudra ${ }^{4}$, \\ ${ }^{1-4}$ Latvia University of Agriculture
}

\begin{abstract}
The objective of the current research is to evaluate the quality changes of shredded carrots treated with 2 ppm ozonated tap water for $60 \mathrm{~s} \pm 1 \mathrm{~s}$. Treated carrots have been packed in several materials (hermetically sealed by breathing polymer film BOPP Propafilm ${ }^{\text {TM }}$ P2GAF, cellulose based biodegradable NatureFlex NVS and Polilactid BIO-PLA Containers) and stored at the temperature of $+4^{\circ} \mathrm{C} \pm 1^{\circ} \mathrm{C}$ for 10 days. Main quality parameters using standard methods have been analysed: total carotenoids and $\beta$-carotene, total phenolic, antioxidant capacity, soluble solids, mass loses, moisture, $\mathrm{pH}$, firmness, colour, $\mathrm{CO}_{2}$ and $\mathrm{O}_{2}$ and microbiological parameters. Testing of the samples has been carried out before packaging and during storage. In the present research it has been proved that is possible to maintain the chemical composition of shredded carrots during storage by treatment of carrots with ozonated tap water; as a result, the shelflife of shredded carrots can prolong till 10 days.
\end{abstract}

Keywords - Carrots, ozone, storage, treatment.

\section{INTRODUCTION}

FRESH-CUT carrots can be found on the market place as whole peeled (baby), sticks, and sliced, shredded, grated and diced. There is shelf life limitation of minimally processed carrots from 4 to 5 days due to a high respiration rate, development of off-flavour, acidification, and loss of firmness, discoloration, and microbial spoilage. Shredded carrots are an increasingly popular product, but their sales are restricted due to rapid deterioration during storage [1]. Fresh-cut fruits and vegetables have been very popular for the bioavailability of numerous vitamins, minerals and other phytochemicals. However, they may contain a wide variety of bacteria, fungi and yeast species [2].

Minimally processed vegetables (MPV) are prepared and handled to maintain their fresh nature while providing convenience to the consumer, as ready-to-eat. Producing MPV involves cleaning, trimming, peeling, coring, slicing, shredding, washing, etc. [3], [4]. Considerable interest, therefore, is currently being expressed in safer and 'environmental-friendly' sanitizing agents, including ozone [5]. The fresh produce industry is showing interest in $\mathrm{O}_{3}$ applications due to growing consumer preference for minimally processed food products, frequent outbreaks of food-related illnesses, identification of new food pathogens, and the passage of legislation governing food quality and safety [6]. Ozone extends the shelf-life of the fresh produce during storage by oxidizing the metabolic products produced during storage of the product [7]. The use of ozone in food processing has become increasingly important as a result of the affirmation of ozone as a GRAS (Generally Recognized as Safe) chemical in 1997 and its subsequent approval by the US FDA as an antimicrobial additive for direct contact with food products of all types (FDA 2001). The Food and Drug Administration (FDA, 2011), under the ruling 21 C.F.R. 173.315, has approved the use of ozone as plant protection agents in the processing of fresh fruits and vegetables. The use of ozone in food processing has been approved to various degrees in many countries, including the USA, Japan, Australia, France and Canada [9], [10], [11], [12], [13] and which has since received formal US-FDA approval (in 2003) as a Food Additive [5]. Ozone is one of the most potent sanitizers known and is effective against a wide spectrum of microorganisms at relatively low concentrations [7]. Ozone has a wide antimicrobial spectrum, which combined with a high oxidation potential, makes it an attractive processing option for the food industry. Relatively small quantities of ozone and short contact times are sufficient for the desired antimicrobial effect and it rapidly decomposes into oxygen, leaving no toxic residues [10], [14]. Within the food industry, ozone has been used routinely for washing and storage of fruits and vegetables. Ozone can be bubbled through water into which it will partially dissolve. The ozonated water then can be used for washing and/or in transfer flumes to reduce the microbial loads of berries and other fruits and vegetables. Controlled studies report that ozonated water may actually provide greater than $90 \%$ reduction of total bacterial counts for some vegetables. Such treatments also have been shown to reduce fungi populations and, subsequently, reduce fungal decay [7]. Though $\mathrm{O}_{3}$ is a GRAS chemical, it is also a toxic gas; toxicity is dependent on concentration and length of exposure [6]. Ozone must be manufactured on site for immediate use since it is unstable and quickly decomposes to normal oxygen. The half-life of ozone in distilled water at $20^{\circ} \mathrm{C}$ is about 20-30 minutes [7], [9], [10], [15]. Ozone is formed from molecular oxygen in an endothermic process, under a very high voltage or UV radiation, as well as from the decomposition of $\mathrm{O}_{2}$ and its further recomposition [16]. Ozone is a naturally occurring substance found in our atmosphere and it can also be produced synthetically. The characteristic fresh, clean smell of air following a thunderstorm represents freshly generated ozone in nature [7]. Therefore, $\mathrm{O}_{3}$ technology is a good option for the wash-water disinfection for the fresh-cut industry, because it will reduce the need for water replacement and for high sanitizer concentration [17]. On the other hand, using ozone as a disinfectant has disadvantages, including its instability and reactivity with organic materials, and, thus, the effective elimination of microorganisms may require high concentrations that may cause sensory defects in fresh produce. In addition, some nutritional components (vitamins, amino acids, enzymes, essential fatty acids) may be altered as a result of oxidation [18].

The objective of the current research is to evaluate the quality changes of shredded carrots treated with ozonated tap water during storage. 


\section{MATERIALS AND METHODS}

\section{A. Materials}

The object of the research was serotinous 'Nante' carrot (Daucus carota L.) hybrid 'Nante/Forto' harvested in Zemgale region (Latvia) in the first part of October 2012 and was immediately used for experiments.

\section{B. Processing, Packaging, and Storage of Carrots}

Carrots were rinsed under the tap water, then peeled and shredded using Philips Comfort HR 7605 device. The disinfection consisted of immersion of shredded carrots in tap water ozonated to a $2 \mathrm{ppm}$ for $60 \mathrm{~min} \pm 1 \mathrm{~min}$. The ozone was produced using the High concentration Ozone water generator and Oxygen generator (SOZ-YWS); ozone concentration in water was measured using DO3 device.

TABLE 1

CHARACTERISATION OF PACKAGING MATERIALS

\begin{tabular}{|c|c|c|l|}
\hline No. & $\begin{array}{c}\text { Packaging } \\
\text { material }\end{array}$ & Thickness & \multicolumn{1}{|c|}{ Barrier properties } \\
\hline 1 & $\begin{array}{c}\text { BOPP } \\
\text { Propafilm } \\
\text { P2GAF }\end{array}$ & $\delta=38 \pm 1 \mu \mathrm{m}$ & $\begin{array}{l}\text { OTR: } 3000 \mathrm{~cm}^{3} / \mathrm{m}^{2} \text { per } 24 \mathrm{hrs} ; \\
\mathrm{CO}_{2} \mathrm{TR}: 12000 \mathrm{~cm}^{3} / \mathrm{m}^{2} 24 \mathrm{hrs} .\end{array}$ \\
\hline 2 & $\begin{array}{c}\text { NatureFlex } \\
\text { NVS film }\end{array}$ & $\delta=35 \pm 1 \mu \mathrm{m}$ & $\begin{array}{l}\text { OTR: } 3000 \mathrm{~cm}^{3} / \mathrm{m}^{2} \text { per } 24 \mathrm{hrs} ; \\
\mathrm{CO}_{2} \mathrm{TR}: 12000 \mathrm{~cm}^{3} / \mathrm{m}^{2} 24 \mathrm{hrs} .\end{array}$ \\
\hline 3 & $\begin{array}{c}\text { Bio-PLA } \\
\text { Containers }\end{array}$ & $\delta=30.0 \mu \mathrm{m}$ & $\begin{array}{l}\text { WTR: } 55 \mathrm{~g} / \mathrm{m}^{2} \mathrm{~d} \pm 10 \% \text { at } 23{ }^{\circ} \mathrm{C} \text { and } \\
\text { HR } 85(\mathrm{ASTM} \mathrm{F} 1249) \\
\text { OTR: } 500 \mathrm{~cm}^{3} / \mathrm{m}^{2} \mathrm{~d} \text { bar at } 23{ }^{\circ} \mathrm{C} \text { and } \\
\text { HR } 50 \%:(\mathrm{DIN} 53380-3)\end{array}$ \\
\hline
\end{tabular}

Shredded carrots were packed by $100 \mathrm{~g} \pm 5.0 \mathrm{~g}$ in DuniForm PP trays (138 mm x $114 \mathrm{~mm}$ x $53 \mathrm{~mm}$ ) hermetically sealed by breathing polymer film BOPP Propafilm ${ }^{\mathrm{TM}}$ P2GAF (Biaxially oriented polypropylene), cellulose based biodegradable NatureFlex NVS and Polilactid BIO-PLA (biodegradable polylactic acid) containers (Table 1).

Samples within 10 days were stored in a Commercial Freezer/Cooler "Elcold" at the temperature of $+4.0 \pm 0.5^{\circ} \mathrm{C}$. The results were reported as mean values of all determinations. Samples were analyzed before packaging (day 0 ) and after 3, 5, 8 and 10 days of storage; ten measurement replications of each sample were performed.

\section{Moisture}

Moisture content was determined by ISO 6496:1999 according to the storage time by verified balance KERN (Germany) with precision $\pm 0.001 \mathrm{~g}$.

\section{D. $p H$}

$\mathrm{pH}$ value was measured using JENWAY $3510 \mathrm{pH}$-meter, by standard method LVS ISO 5542:2010.

\section{E. Mass Losses}

The sample mass was determined by a digital precision balance $( \pm 0.1 \mathrm{~g})$. At each sampling time, for each type of carrots, the mass was measured three times on different samples [19].

\section{F. $\beta$-carotene}

For extraction, a representative portion of the sample $(1 \mathrm{~g})$ was accurately weighed in a glass test tube. Then $5 \mathrm{ml}$ of chilled acetone was added, and the tube was held for $15 \mathrm{~min}$ with occasional shaking at $4^{\circ} \mathrm{C} \pm 1^{\circ} \mathrm{C}$, vortex at a high speed for $10 \mathrm{~min}$, and finally centrifuged at $1370 \times \mathrm{g}$ for $10 \mathrm{~min}$. Supernatant was collected into a separate test tube, and the compound was re-extracted with $5 \mathrm{ml}$ of acetone followed by centrifugation once again as above. Both of the supernatants were pooled together and then passed through the Whatman filter paper No. 42. The absorbance of the extract was determined at $449 \mathrm{~nm}$ wavelength in a UV-Vis spectrophotometer [20]. Blank samples for raw carrots were prepared as described above. A working standard containing $32 \mu \mathrm{g} \mathrm{ml}^{-1}$ was prepared from $1 \mathrm{mg}$ $\mathrm{ml}^{-1}$ stock solutions kept at $4{ }^{\circ} \mathrm{C}$. From this working standard, different dilutions were made to spike the samples. Blank samples of $1.0 \mathrm{~g}$ were spiked with working standards to obtain final concentrations $16.0 \mu \mathrm{g} \mathrm{g}^{-1}, 8.0 \mu \mathrm{g} \mathrm{g}^{-1}, 4.0 \mu \mathrm{g} \mathrm{g}^{-1}, 2.0 \mu \mathrm{g} \mathrm{g}^{-1}$, $1.0 \mu \mathrm{g} \mathrm{g}^{-1}, 0.5 \mu \mathrm{g} \mathrm{g}^{-1}, 0.25 \mu \mathrm{g} \mathrm{g}^{-1}, 0.125 \mu \mathrm{g} \mathrm{g}^{-1}, 0.062 \mu \mathrm{g} \mathrm{g}^{-1}$, $0.031 \mu \mathrm{g} \mathrm{g}^{-1}$ and $0.015 \mu \mathrm{g} \mathrm{g}^{-1}$ of $\beta$-carotene and extracted as described previously. Calibration curves were plotted by taking Optical Density value to the respective concentrations by back extrapolation methods. These curves were used to quantify the $\beta$-carotene content in the samples analyzed [20].

\section{G. Total Carotenoids}

Total carotenoids were analyzed by a spectrophotometric method (used the UV/VIS spectrophotometer Jenway 6300) at $440 \mathrm{~nm}$ [21]. A sample of $1 \mathrm{~g}$ of homogenized shredded carrots sample was placed in $100 \mathrm{ml}$ conic flask and $30 \mathrm{ml}$ of $96 \%$ ethanol was added. The sample was stirred on a magnetic stirrer for $15 \mathrm{~min}$ then $25 \mathrm{ml}$ of petrolether was added and stirring was continued for one more hour. After 1 hour when both layers were completely divided, the top yellow layer was used for further detection of carotenoids at $440 \mathrm{~nm}$. Carotene equivalent (KE) was found, using a graduation curve with $\mathrm{K}_{2} \mathrm{Cr}_{2} \mathrm{O}_{7}$.

\section{H. Colour Analysis}

Colour of the carrots was evaluated by measuring CIE L*, $\mathrm{a}^{*}$, and $\mathrm{b}^{*}$ parameters by means of "ColorTec-PCM/PSM", (ColorTec Associates, Clinton, USA). L*, $\mathrm{a}^{*}$, and $\mathrm{b}^{*}$ indicate whiteness/darkness, redness/greenness, and blueness/yellowness values, respectively. The maximum value for $\mathrm{L}^{*}$ is 100 , which would be a perfect reflecting diffuser. The minimum for $\mathrm{L}^{*}$ is zero: black. The values of $\mathrm{a}^{*}$ and $\mathrm{b}^{*}$ axes have no specific numerical limits. Positive $a^{*}$ is red and negative $a^{*}$ is green. Positive $b^{*}$ is yellow and negative $b^{*}$ is blue [22].

\section{Total Phenolics}

The total phenolic content of carrots was determined using Folin-Ciocalteu colorimetric method [23], [24]. Total phenolic content was expressed as gallic acid equivalent (GAE) $100 \mathrm{~g}^{-1}$ dry weight (DW) of the sample.

\section{J. Total Antioxidant Capacity (DPPH')}

The antioxidant capacity of carrots was measured by the DPPH radical method according to Faller and Fialho [25]. Inhibition of $\mathrm{DPPH}^{*}$ in percent $(I \%)$ of each extract sample was calculated as follows:

$$
\% I=\frac{A_{0}-A_{t}}{A_{0}} \times 100
$$

where $A_{0}$ represents the absorbance of DPPH solution alone measured at zero time, and $A_{t}$ is the absorbance for each sample 
at the times of $15 \mathrm{~min}, 30 \mathrm{~min}$ and $60 \mathrm{~min}$ after the addition of the DPPH solution. The value of $A_{0}$ is considered $100 \%$ [25].

\section{K. Soluble Solids}

The content of soluble solids ( $\left({ }^{\circ} \mathrm{Brix}\right)$ was determined at the temperature of $+20^{\circ} \mathrm{C} \pm 2{ }^{\circ} \mathrm{C}$ with a digital refractometer (deviation of measuring instrument face value $\pm 0.1 \%$ ) by standard method ISO 2173:2003.

\section{Firmness}

A structure analyser "TA.XT.plus texture Analyser" (Stable Micro Systems Ltd., Surrey, UK) and measuring probe HDP/BSK (blade set with knife, supplied with the Texture Analyser) were used for firmness determination. The system was equipped with a compression cell of $50 \mathrm{~kg}$ and software Texture Exponent 32. Firmness was measured as the maximum penetration force $(\mathrm{N})$ reached during tissue breakage. The measuring parameters were: pre-test speed $2 \mathrm{~mm} \mathrm{~s}^{-1}$; test speed $2 \mathrm{~mm} \mathrm{~s}^{-1}$; post-test speed $10 \mathrm{~mm} \mathrm{~s}^{-1}$; penetrating distance $23 \mathrm{~mm}$ into the carrot. The measurement was triggered automatically at $0.04903 \mathrm{~N}$. The maximum force required for sample cutting was calculated as an average of 10 measurements [26].

\section{Microbiological Analyses}

Samples for microbiological testing were prepared by a dilution method in conformity with standard LVS EN ISO 6887-1:1999 and 6887-4:2044. TPC (total plate count) determined in conformity with standard LVS EN ISO 4833:2003A; yeast and mould plate count - determined in conformity with standard LVS ISO 21527-2:2008. Plate counts were evaluated as decimal logarithm of colony forming units (CFU) per gram of a product $\left(\log \mathrm{cfu} \mathrm{g}^{-1}\right)$.

\section{N. Gas Composition}

The dynamics of gas composition inside each hermetically sealed package headspace within the storage time was measured as a percentage of oxygen and carbon dioxide by a gas analyzer OXYBABY ${ }^{\circledR V} \mathrm{O}_{2} / \mathrm{CO}_{2}$. The packs were sampled in duplicate, and the whole experiment was repeated three times.

\section{O. Mathematical Data Processing}

The results were processed by statistical methods. Statistics on a completely randomized design was determined using the General Linear Model (GLM) procedure SPSS, version 16.00. Two-way analyses of variance $(p \leq 0.05)$ were used to determine significance of differences between different samples.

\section{RESULTS AND DISCUSSION}

\section{A. $\mathrm{O}_{2}$ and $\mathrm{CO}_{2}$ Composition}

$\mathrm{CO}_{2}$ and $\mathrm{O}_{2}$ gas composition changes inside a package during storage of carrots for 10 days are presented in Fig. 1 and Fig. 2. It was determined that oxygen content changes inside a package with non-treated carrot samples were significant $(p=0.024)-$ the content decreased compared to the acquired results of carrots treated in ozonated water during the same time of storage. Significant results were observed in experiments, when shredded carrots were packaged in Polilactid BIO-PLA containers and BOPP Propafilm ${ }^{\mathrm{TM}}$ P2GAF. Namely, inside Polilactid BIO-PLA packaging the content of $\mathrm{O}_{2}$ approached $10.9 \%$; however, inside BOPP Propafilm ${ }^{\mathrm{TM}}$ P2GAF films $10.1 \%$.

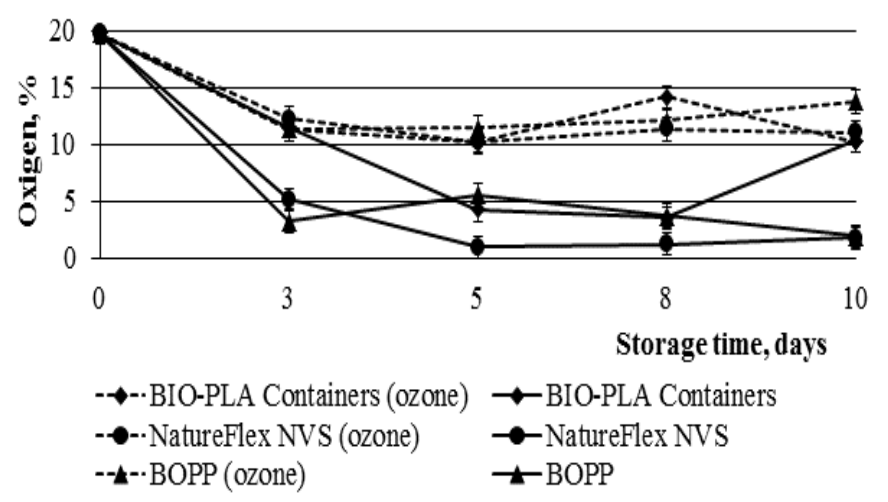

Fig. 1. $\mathrm{O}_{2}$ dynamics inside a package of shredded carrots during storage.

Differences in oxygen composition changes inside a package during storage of carrots could mainly be explained with different airtightness of packaging.

As can be seen in Fig. 1, $\mathrm{O}_{2}$ values (obtained after 10 days of storage) ranged between $1.8 \%-10.4 \%$, depending on the type of packaging. However, low $\mathrm{O}_{2}$ amount could be deemed favorable for the reduction of enzymatic browning [4].

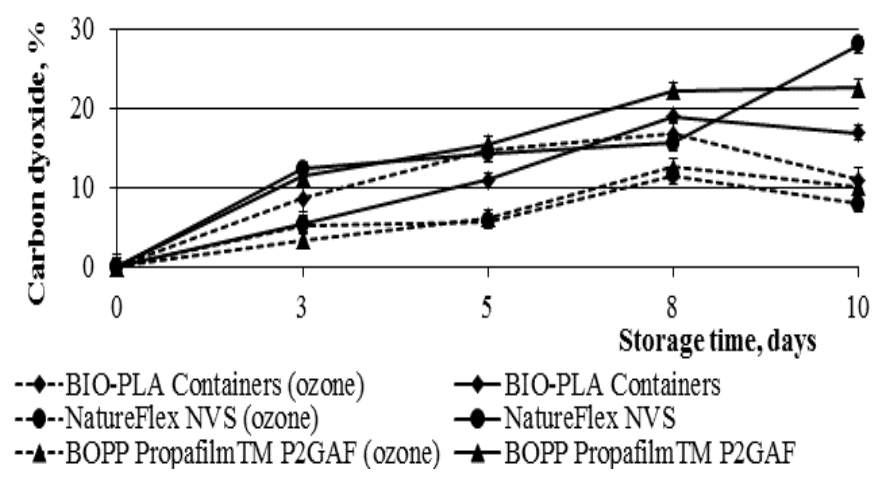

Fig. 2. $\mathrm{CO}_{2}$ dynamics inside a package of shredded carrots during storage.

Insignificant differences were found in carbon dioxide content $(p=0.594)$ inside a package with ozonated and nonozonated carrots after 10 days. It is necessary to indicate that Gomez-Lopez (2012) reported that the level of ozone treatment was beneficial for retarding the physiological metabolism of carrots and thereby maintaining the quality during 9 days of storage [27].

\section{B. Total Phenols and Total Antioxidant Capacity}

The results of the present study indicated that the content of total phenols of shredded carrots treated with ozonated water decreased during storage, but the decrease after ten days of storage was not significant $(p=0.096)$. It was determined that it was possible to maintain phenolic compounds in carrots by processing them shortly with ozonated water.

Significant differences in antioxidant capacity $(p=0.006)$ were observed between treated and non-treated (control) shredded samples after ten days of storage (Fig. 3). 


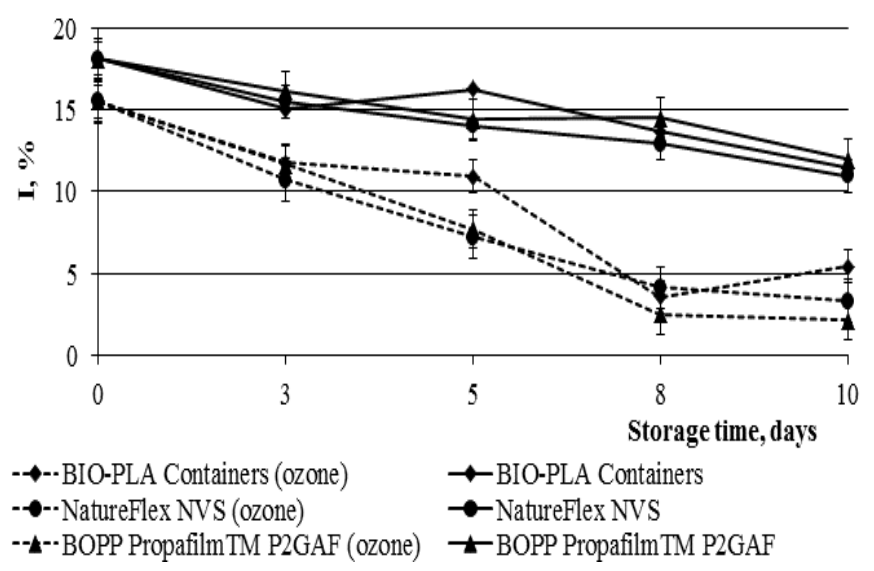

Fig. 3. DPPH dynamics of shredded carrots during storage.

The antioxidant capacity value of non-ozonated samples after ten days of storage was $10.96 \%-11.98 \%$ and $2.12 \%-5.43 \%$ of ozonated samples (Fig. 3) that was 5-2 times less comparing with non-ozonated shredded carrots depending on the packaging material.

\section{Total Carotenoids and $\beta$-carotene; Colour}

Carotenoids in fresh-cut products are highly susceptible to oxidative deterioration due to the enhanced susceptibility under acute abiotic stress. In the present study, ozonation reduced the content of carotenoids in shredded carrots. In general, a negative impact was not reported for ozone and carotenoids, $\beta$ carotene contents of the shredded carrots.

Gomez-Lopez (2012) reported that ozone treatment (10 $\left.\mathrm{mg} \mathrm{L}^{-1}-10 \mathrm{~min}\right)$ significantly reduced carotenoid contents in sliced carrots. However, the differences between the control and ozonated samples at the end of 30 days of storage were actually small [27].

Experimentally, it was established that there were no significant differences in carotenoid and $\beta$-carotene content after 10 days of storage of all carrot samples packed in different materials and treated with ozonated water $(p=0.115$ and $p=0.597)$ comparing with non-stored fresh samples. Chauhan et al. (2011) have reported that since carotenoids undergo rapid auto-oxidation by reactivity with molecular oxygen, the protective mechanism by means of enzymatic reduction is minimal. The oxidative effect of ozone on food products is described as a surface phenomenon [28].

Food processing has both positive and negative effects on the levels of carotenoids in food, but overall it is more evident that processing may be beneficial through the disruption of a matrix (cell walls), which facilitates their release and solubilisation as free or esterified/glycosylated forms in appropriate solvents, or after long heating times, leading to chemical changes [29].

The colour of carrot roots results mainly from pigment accumulation in the root tissue. The roots of the investigated carrot cultivars differed with respect to $\mathrm{L}^{*}, \mathrm{a}^{*}$ and $\mathrm{b}^{*}$ colour parameters. The influence of different packaging materials and storage time on the values of lightness $\left(\mathrm{L}^{*}\right)$, redness component $\left(a^{*}\right)$, and yellowness component $\left(b^{*}\right)$ are shown in Table 2.
TABLE 2

Colour InTENSITY of CARRots DEPENDING ON PACKAGING MATERIALS AND STORAGE TIME

\begin{tabular}{|c|c|c|c|c|}
\hline \multirow{2}{*}{$\begin{array}{c}\text { Packaging } \\
\text { material }\end{array}$} & \multirow{2}{*}{$\begin{array}{c}\text { Storage } \\
\text { time, } \\
\text { days }\end{array}$} & \multicolumn{3}{|c|}{ Colour intensity } \\
\hline & & $\mathrm{L}^{*}$ & $a^{*}$ & $b^{*}$ \\
\hline \multicolumn{5}{|c|}{ Shredded carrots treated with ozonated water } \\
\hline \multirow{5}{*}{$\begin{array}{l}\text { BIO-PLA } \\
\text { Containers }\end{array}$} & 0 & $45.67 \pm 1.70$ & $17.06 \pm 0.74$ & $41.44 \pm 2.90$ \\
\hline & 3 & $44.84 \pm 2.14$ & $16.71 \pm 0.75$ & $36.05 \pm 2.63$ \\
\hline & 5 & $44.52 \pm 1.41$ & $17.80 \pm 0.97$ & $37.37 \pm 2.60$ \\
\hline & 8 & $45.46 \pm 1.75$ & $17.83 \pm 1.59$ & $36.83 \pm 2.09$ \\
\hline & 10 & $42.81 \pm 1.26$ & $17.26 \pm 0.24$ & $39.27 \pm 1.72$ \\
\hline \multirow{5}{*}{$\begin{array}{c}\text { NatureFlex } \\
\text { NVS }\end{array}$} & 0 & $45.67 \pm 1.70$ & $17.06 \pm 0.74$ & $41.44 \pm 2.90$ \\
\hline & 3 & $44.71 \pm 0.52$ & $17.06 \pm 1.31$ & $36.06 \pm 2.00$ \\
\hline & 5 & $44.07 \pm 0.35$ & $16.49 \pm 0.95$ & $35.34 \pm 2.42$ \\
\hline & 8 & $44.84 \pm 2.30$ & $16.41 \pm 1.52$ & $37.14 \pm 2.84$ \\
\hline & 10 & $43.10 \pm 0.33$ & $16.67 \pm 0.79$ & $40.05 \pm 1.68$ \\
\hline \multirow{5}{*}{$\begin{array}{c}\text { BOPP } \\
\text { Propafilm }^{\mathrm{TM}} \\
\text { P2GAF }\end{array}$} & 0 & $45.67 \pm 1.70$ & $17.06 \pm 0.74$ & $41.44 \pm 2.90$ \\
\hline & 3 & $45.35 \pm 1.59$ & $15.70 \pm 1.69$ & $36.06 \pm 2.19$ \\
\hline & 5 & $44.06 \pm 1.78$ & $17.21 \pm 0.77$ & $35.66 \pm 3.27$ \\
\hline & 8 & $46.10 \pm 1.00$ & $15.76 \pm 1.72$ & $37.34 \pm 3.83$ \\
\hline & 10 & $43.11 \pm 1.02$ & $16.39 \pm 0.91$ & $36.18 \pm 3.36$ \\
\hline \multicolumn{5}{|c|}{ Shredded carrots non-treated with ozonated water } \\
\hline \multirow{5}{*}{$\begin{array}{l}\text { BIO-PLA } \\
\text { Containers }\end{array}$} & 0 & $56.79 \pm 0,39$ & $22.21 \pm 0.93$ & $44.93 \pm 0.85$ \\
\hline & 3 & $56.43 \pm 0,96$ & $20.75 \pm 0.81$ & $43.73 \pm 0.58$ \\
\hline & 5 & $54.42 \pm 1.64$ & $20.68 \pm 1.52$ & $42.85 \pm 1.02$ \\
\hline & 8 & $53.85 \pm 0.68$ & $20.17 \pm 0.37$ & $40.94 \pm 0.63$ \\
\hline & 10 & $53.14 \pm 0.52$ & $19.89 \pm 0.62$ & $39.14 \pm 1.73$ \\
\hline \multirow{5}{*}{$\begin{array}{c}\text { NatureFlex } \\
\text { NVS }\end{array}$} & 0 & $56.79 \pm 0,39$ & $22.21 \pm 0.93$ & $44.93 \pm 0.85$ \\
\hline & 3 & $54.20 \pm 0.72$ & $17.80 \pm 0.91$ & $34.55 \pm 1.43$ \\
\hline & 5 & $57.15 \pm 1.18$ & $19.89 \pm 0.56$ & $35.05 \pm 1.19$ \\
\hline & 8 & $56.42 \pm 0.42$ & $19.27 \pm 0.72$ & $34.73 \pm 0.27$ \\
\hline & 10 & $55.63 \pm 0.84$ & $18.73 \pm 0.32$ & $34.21 \pm 0.36$ \\
\hline \multirow{5}{*}{$\begin{array}{c}\text { BOPP } \\
\text { Propafilm }^{\mathrm{TM}} \\
\text { P2GAF }\end{array}$} & 0 & $56.79 \pm 0.39$ & $22.21 \pm 0.93$ & $44.93 \pm 0.85$ \\
\hline & 3 & $57.23 \pm 1.08$ & $20.44 \pm 1.12$ & $43.97 \pm 1.31$ \\
\hline & 5 & $54.20 \pm 0.84$ & $20.51 \pm 0.31$ & $20.51 \pm 0.31$ \\
\hline & 8 & $53.94 \pm 0.58$ & $19.75 \pm 0.64$ & $42.97 \pm 0.62$ \\
\hline & 10 & $53.26 \pm 0.52$ & $19.37 \pm 0.73$ & $41.74 \pm 0.61$ \\
\hline
\end{tabular}

There were no big differences found in redness component $\left(\mathrm{a}^{*}\right)$ and yellowness component $\left(b^{*}\right)$ values between the analyzed carrot samples that mainly could demonstrate a similar colour of analyzed carrots. The values of lightness $\left(\mathrm{L}^{*}\right)$ markedly differed $(p<0.05)$ comparing ozonated and non-ozonated carrot samples during storage in different packaging materials.

Martín-Belloso and Soliva-Fortuny (2011) reported that carrots exposed to ozone gas during storage had a lighter, less intense colour than untreated carrots [17]. In another study with ozone, carrots showed an increase in luminosity after processing and decrease in the chrome [11]. Similar results were obtained in the present research, too. 


\section{Soluble Solids}

In the present research, significant differences $(p=0.026)$ in the content of soluble solids between ozonated and nonozonated carrots were obtained (Fig. 4). It means that ozone negatively influences soluble solid content in carrots; as a result, it decreased by $33 \%$.

However, a very similar tendency was observed in changes in the content of soluble solids in ozonated and non-ozonated shredded carrots during their storage (Fig. 4). It was detected that after 10 days of storage, not depending of packaging material, the decrease in the content of soluble solids in ozonated carrots was $10 \%$ and in non-ozonated carrots $-8 \%$ that is not significant $(p=0.448$ and $p=0.281)$.
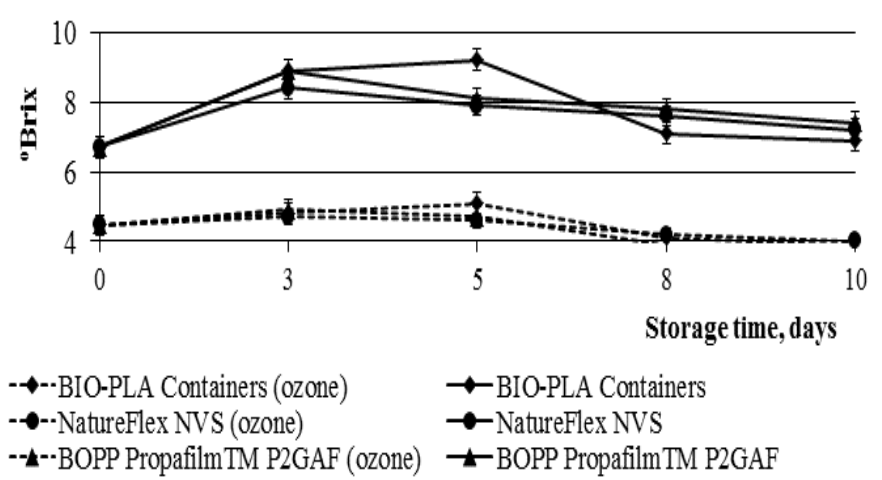

Fig. 4. Dynamics of soluble solids of shredded carrots during storage.

On the last day of storage, only main differences between ozonated and non-ozonated shredded carrot samples in the content of soluble solids were established.

\section{E. $p H$}

In the present research, it was proved that ozonated water insignificantly $(p=0.447)$ influenced $\mathrm{pH}$ value of shredded carrots (Fig. 5). However, it is necessary to indicate that $\mathrm{pH}$ value of ozonated carrots was lower after 10 days of storage compared to $\mathrm{pH}$ value of non-ozonated carrots.

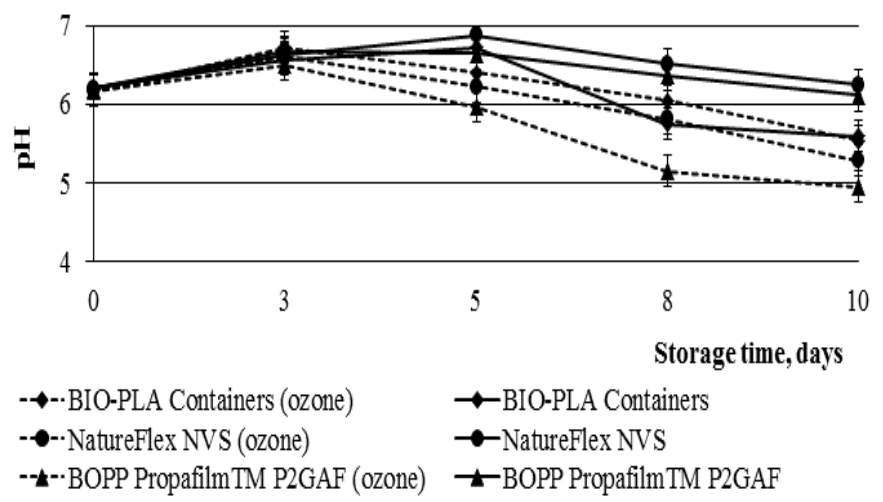

Fig. 5. Dynamics of $\mathrm{pH}$ value of shredded carrots during storage.

Significant influence of packaging material on $\mathrm{pH}$ value changes of ozonated and non-ozonated carrots was detected. As a result, a decrease in $\mathrm{pH}$ value was obtained in carrots packaged in BOPP Propafilm ${ }^{\mathrm{TM}} \mathrm{P} 2 \mathrm{GAF}$ for ozonated and nonozonated carrots.

However, not so pronounced decrease in $\mathrm{pH}$ value was obtained in carrots packaged in Polilactid BIO-PLA.

\section{F. Moisture and Mass Losses}

Water migration phenomena and the resulting moisture content change in food products affect their shelf-life through undesirable modifications of their physical, sensory and microbial qualities [30]. Therefore, it is very important to determine the moisture content of shredded carrots in a package to foresee their shelf-life in general. Experimentally, it was established that insignificant differences in moisture content and mass loss values after 10 days of storage of all analysed shredded carrot samples packed in different packaging materials were found $(p=0.208$ and $p=0.157)$.

\section{G. Firmness}

Texture is a critically important component of fresh-cut fruit and vegetable quality, which is difficult to analyze commercially. Due to commercial difficulties in testing product quality, it is often assumed that "if it looks good, it tastes good" [17]. Significant influence $(p=0.043)$ of ozone on firmness of shredded carrots was detected in the present research. Firmness changes of shredded carrot samples during storage in various packaging materials are presented in Fig. 6.

In the present experiments it was detected that ozonated shredded carrots were harder than non-ozonated carrots - the firmness value of ozonated shredded carrots was by $19 \%$ higher compared to non-ozonated carrots at the beginning of storage. The increase in a firmness value was obtained in carrots during their storage, as well (Fig. 6) that could mainly be explained with moisture migration through the packaging material as well as some biochemical and chemical processes occurring during the storage, which promoted hardening.

In total, a significant increase in the firmness value of analyzed carrot samples $(p=0.015)$ was obtained in present experiments after 10 days of storage. Although the biggest fluctuations of firmness during the storage were detected in non-ozonated samples, only a slight increase in a firmness value was obtained in ozonated carrots that could mainly be explained with possible postharvest changes in cellulose and hemicellulose contents due to $\mathrm{O}_{3}$ [6].

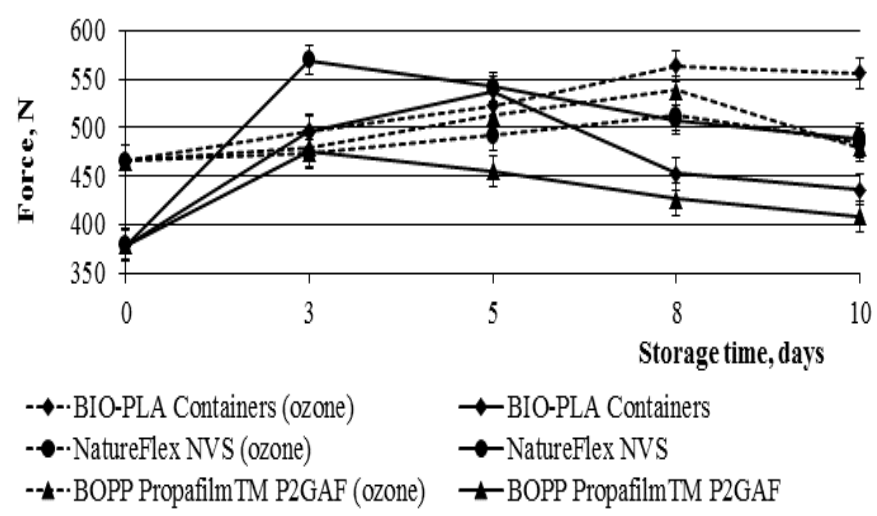

Fig. 6. Dynamics of firmness value of shredded carrots during storage.

\section{H. Microbiological Parameters}

Microorganisms are an important factor to consider in dealing with MP fresh fruits and vegetables because microbial spoilage has economic consequences of importance but most importantly because consumer safety is at risk with foodborne 
illness [31]. However, ozonation is used as a surface decontamination method for fruits and vegetables [28].

In the present research it was proved that it was possible to provide the microbiological safety of shredded carrots by their treatment with ozonated water. As a result, it was possible to decrease the total count of microorganisms and moulds (Fig. 7 and Fig. 8).

In the present study, it was found that by treatment of carrots with ozonated water it was possible to significantly ( $p=0.0001)$ reduce standard plate count (SPC) by $8.83 \log \mathrm{cfu}^{-1}$. It mainly indicates that the potency of $\mathrm{O}_{3}$ as an effective agent against a wide range of both pathogenic and spoilage microorganisms at relatively low concentrations makes it attractive for food applications [6].

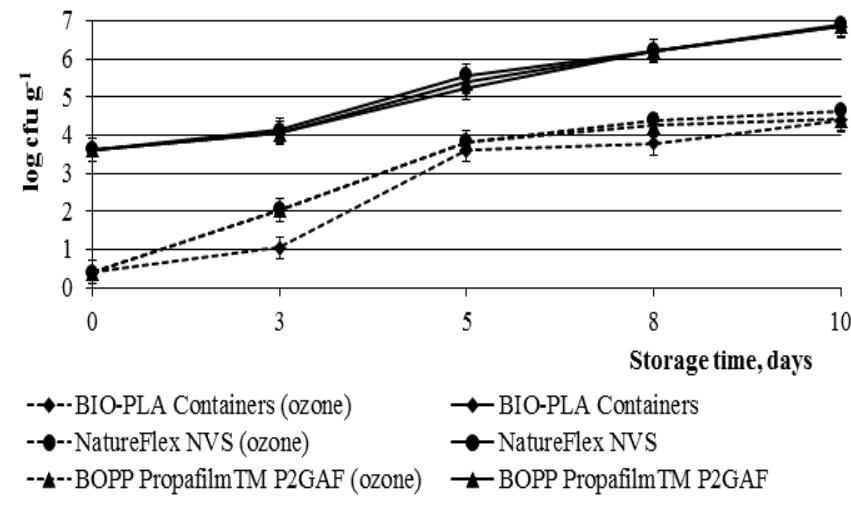

Fig. 7. MAFAm dynamics of shredded carrots during storage.

Jacxsens et al. (2003) reported that the microbial load should not be more than $5.70 \log \mathrm{cfu} \mathrm{g}^{-1}$ in order to guarantee 5-6 days of shelf life for minimally processed carrots [32].

In the present study, it was found that the total aerobic mesophilic bacteria count of shredded carrots treated with ozonated water was around $4.63 \log \mathrm{cfu} \mathrm{g}^{-1}$ on the $10^{\text {th }}$ day of storage; however, similar results for non-treated carrots were acquired on the $5^{\text {th }}$ day of storage. Therefore, it is possible to conclude that the shelf-life of shredded carrots could be 5 days longer if they could be treated with ozonated water before packaging.

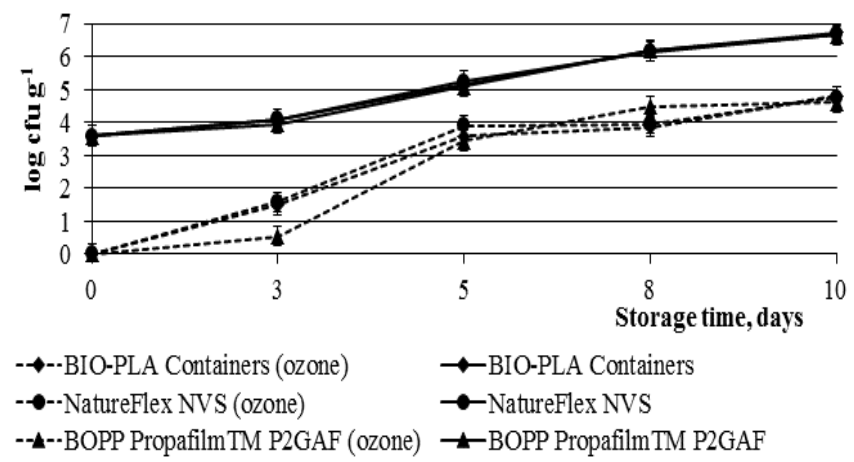

Fig. 8. Mould count dynamics of shredded carrots during storage.

The presence of $E$. coli in the tested samples of shredded carrots treated with ozone has not been detected in any sample, confirming that this product does not offer a risk factor for the consumers' health.

\section{CONCLUSIONS}

Within experiments it was ascertained that ozonated water significantly influenced antioxidant capacity and content of soluble solids, firmness value and microbiological parameters of fresh shredded carrots; however, it did not significantly influence phenolic compounds, carotenoids and $\beta$-carotene content, color changes and $\mathrm{pH}$ value.

During experiments it was ascertained that it was possible to maintain the quality of shredded carrots during storage in several packaging materials mainly by their treatment with ozonated water.

Shelf-life of shredded carrots treated with ozonated water is 10 days, and that of non-treated carrots -5 days.

It was proved that the packaging materials tested within the research insignificantly influenced quality parameters of analyzed shredded carrots during their storage. However, more recommendable Polilactid BIO-PLA containers could be indicated.

\section{ACKNOWLEDGMENTS}

The authors would like to express sincere gratitude to Juris Brūveris from Ltd. "O Trīs" (Latvia) for technical advice in carrot treatment with ozonated water.

\section{REFERENCES}

[1] Barry-Ryan C., Pacussi J.M., O'Beirne D. Quality of shredded carrots as affected by packaging film and storage temperature. Journal of Food Science, 2000, vol. 65, 4, pp. 726-730. http://dx.doi.org/10.1111/j.1365-2621.2000.tb16080.x

[2] Tornuk F., Cankurt H., Ozturk I., et al. Efficacy of various plant hydrosols as natural food sanitizers in reducing Escherichia coli O157:H7 and Salmonella Typhimurium on fresh cut carrots and apples. International Journal of Food Microbiology, 2011, vol. 148, pp. 30-35. http://dx.doi.org/10.1016/j.ijfoodmicro.2011.04.022

[3] Ayhan Z., Esturk O., Tas E. Effect of Modified Atmosphere Packaging on the Quality and Shelf Life of Minimally Processed Carrots. Turkish Journal of Agriculture and Forestry, 2008, vol. 32, pp. 57-64.

[4] Baur S., Klaiber R., Hammes W. P., Carle R. Sensory and microbiological quality of shredded, packaged iceberg lettuce as affected by pre-washing procedures with chlorinated and ozonated water. Innovative Food Science and Emerging Technologies, 2004, vol. 5, pp. 45-55. http://dx.doi.org/10.1016/j.ifset.2003.10.002

[5] Tzortzakis N., Borland A., Singleton I., Barnes J. Impact of atmospheric ozone-enrichment on quality-related attributes of tomato fruit. Postharvest Biology and Technology, 2007, vol. 45, pp. 317-325. http://dx.doi.org/10.1016/j.postharvbio.2007.03.004

[6] Rodrigues S., Fernandes F.A.N. Advances in Fruit Processing Technologies. Boca Raton: Taylor \& Francis Group, LLC, 2012, 454 p. http://dx.doi.org/10.1201/b12088

[7] Farid M.M. Mathematical Modeling of Food Processing. Taylor and Francis Group, LLC, Boca Raton, 2010, pp. 607-622. http://dx.doi.org/10.1201/9781420053548

[8] Forney C.F., Song J., Hildebrand P.D., Fan L., McRae K.B. Interactive effects of ozone and 1-methylcyclopropene on decay resistance and quality of stored carrots. Postharvest Biology and Technology, 2007, vol. 45, pp. 341-348. http://dx.doi.org/10.1016/j.postharvbio.2007.03.006

[9] O'Donnell C., Tiwari B.K., Culen P.J., Rice R.G. Ozone in food processing. First Edition. John Wiley \& Sons, Ltd, The Atrium, 2012, 308 p.

[10] Ahmed J., Ramaswamy H.S., Kasapis S., Boye J.I. Novel Food Processing: Effects on Rheological and Functional Properties. Taylor and Francis Group, LLC, Boca Raton, 2010, pp. 127-146.

[11] Bermúdez-Aguirre D., Barbosa-Cánovas G.V. Disinfection of selected vegetables under nonthermal treatments: Chlorine, acid citric, ultraviolet light and ozone. Food Control, 2013, vol. 29, pp. 82-90. http://dx.doi.org/10.1016/j.foodcont.2012.05.073 
[12] Hildebrand P.D., Forney C.F., Song J., Fan L., McRae K.B. Effect of a continuous low ozone exposure $(50 \mathrm{~nL} \mathrm{~L}-1)$ on decay and quality of stored carrots. Postharvest Biology and Technology, 2008, vol. 49, pp. 397-402. http://dx.doi.org/10.1016/j.postharvbio.2008.03.012

[13] Tirpanalan Ö., Zunabovic M., Domig K.J., Kneifel W. Mini review: Antimicrobial strategies in the production of fresh-cut lettuce products. Science against microbial pathogens: communicating current research and technological advances, (Edition) A. Mendez-Vilas. Formatex, Badajoz., 2011, pp. 176-188.

[14] Klaiber R.G., Baur S., Wolf G., et al. Quality of minimally processed carrots as affected by warm water washing and chlorination. Innovative Food Science and Emerging Technologies, 2005, vol. 6, pp. 351-362. http://dx.doi.org/10.1016/j.ifset.2005.03.002

[15] Gomez-Lopez V.M. Decontamination of Fresh and Minimally Processed Produce. Chichester: John Wiley \& Sons, 2012, 554 p. http://dx.doi.org/10.1002/9781118229187

[16] Boskou D., Elmadfa I. Frying of Food. Oxidation, Nutrient and NonNutrient Antioxidants, Biologically Active Compounds and High Temperatures, Second Edition. Taylor and Francis Group, LLC, Boca Raton, 2011, $328 \mathrm{p}$.

[17] Martín-Belloso O., Soliva-Fortuny R. Advances in Fresh-Cut Fruits and Vegetables Processing. Taylor and Francis Group, LLC; Boca Raton, 2011, $410 \mathrm{p}$.

[18] Olaimat A.N., Holley R.A. Factors influencing the microbial safety of fresh produce: A review. Food Microbiology, 2012, vol. 32, pp. 1-19. http://dx.doi.org/10.1016/j.fm.2012.04.016

[19] Mastromatteo M., Conte A., Nobile M.A.D. Packaging strategies to prolong the shelf life of fresh carrots (Daucus carota L.). Innovative Food Science and Emerging Technologies, 2012, vol. 13, pp. 215-220. http://dx.doi.org/10.1016/j.ifset.2011.10.010

[20] Biswas A. K., Sahoo J., Chatli M. K. A simple UV-Vis spectrophotometric method for determination of $\beta$-carotene content in raw carrot, sweet potato and supplemented chicken meat nuggets. Food Science and Technology, 2011, vol. 44, iss. 8, pp. 1809-1813.

[21] Kampuse S., Berna E., Muizniece-Brasava S., et al. Influence of active packaging on the quality of pumpkin - rowanberry marmalade candies. World Academy of Science, Engineering and Technology, 2012, vol. 67, pp. 1135-1143.

[22] Faller A.L.K., Fialho E. Polyphenol content and antioxidant capacity in organic and conventional plant foods. Journal Food Composition and Analysis, 2010, vol. 23, 6, pp. 561-568. http://dx.doi.org/10.1016/i.jfca.2010.01.003

[23] Marinova D., Ribarova F., Atanassova M. Total phenolics and total flavonoids in Bulgarian fruits and vegetables. Journal of the University of Chemical Technology and Metallurgy, 2005, vol. 40, 3, p. 255-260.

[24] Baydar N.G., Sagdic O., Ozkan G., Cetin S. Determination of antibacterial effects and total phenolic contents of grape (Vitis Vinifera L.) seed extracts. Journal Food science and technology, 2006, vol.41, 7, pp. 799-804.

[25] Augspole I., Rakcejeva T., Skudra L., Cinkmanis I. Preservation of shredded carrots by treatment with ozonated water. In: EuroFoodChem XVII: Book of abstracts, Istanbul, Turkey, Hacettepe University, Food Engineering Department, 2013, 422 p.

[26] Augšpole I., Rakčejeva T., Grāmatiṇa I. Changes of physicallychemical parameters of 'Nante' carrot hybrids during storage in traditional conditions. Proceedings of the Latvian Academy of Sciences. Section B. 2013, vol. 67, No. 4 (685), pp. 20-30.

[27] Gomez-Lopez V.M. Decontamination of Fresh and Minimally Processed Produce. Chichester: John Wiley \& Sons, 2012, 554 p. http://dx.doi.org/10.1002/9781118229187
[28] Chauhan O.P., Raju P.S., Ravi N., et al. Effectiveness of ozone in combination with controlled atmosphere on quality characteristics including lignification of carrot sticks. Journal of Food Engineering, 2011, 102, pp. 43-48. http://dx.doi.org/10.1016/j.jfoodeng.2010.07.033

[29] Patras A., Brunton N., Pieve S.D., et al. Effect of thermal and high pressure processing on antioxidant activity and instrumental colour of tomato and carrot purées. Innovative Food Science and Emerging Technologies, 2009, vol. 10, pp. 16-22. http://dx.doi.org/10.1016/j.ifset.2008.09.008

[30] Roca E., Broyart B., Guillard V., et al. Predicting moisture transfer and shelf-life of multidomain food products. J. Food Engineering, 2008, vol. 86, iss. 1, pp. 74-83. http://dx.doi.org/10.1016/j.jfoodeng.2007.09.012

[31] Orsat V., Garie'py Y., Raghavan G.S.V., Lyew D. Radio-frequency treatment for ready-to-eat fresh carrots. Food Research International, 2001, 34, pp. 527-536. http://dx.doi.org/10.1016/S0963-9969(01)00068-0

[32] Jacxsens L., Devlieghere F., Ragaert P., et al. Relation between microbiological quality, metabolite production and sensory quality of equilibrium modified atmosphere packaged fresh-cut produce. Food Microbiology, 2003, vol. 83, pp. 263-280.

http://dx.doi.org/10.1016/S0168-1605(02)00376-8

Ingrida Augspole, Mg. cib. hyg., third-year doctoral student at the Latvia University of Agriculture, Faculty of Food Technology, Department of Chemistry. She was born in Latvia, Madona, in 1972. She received her Master's Degree in Food Hygiene from the Latvia University of Agriculture in 2010. Main scientific directions are: quality evaluation and processing of wild berries, apples, honey, carrots and potatoes. She is the author of 16 scientific articles.

E-mail: ingrida.augspole@inbox.lv

Tatjana Rakcejeva, Dr. sc. ing, Associated Professor. She was born in Latvia, Dobele, in 1977. She received her Doctor Degree in Food Science in 2006. She has been an Associated Professor at the Latvia University of Agriculture since 2010. Main scientific directions are: alternative processes and technologies for processing of meat, fish, berries and vegetables (especially dying possibilities in vacuum microwave drier), development of new food products and their quality evaluation, prolonging possibilities of food shelf-life and food shelf-life prediction. She is the author of about 60 scientific articles.

E-mail: tatjana.rakcejeva@1lu.lv

Lija Dukalska, Dr. habil. sc. ing, Professor. She was born in Latvia, Riga, in 1934. She received her Doctoral Degree in Food Science and Technology in 1972, Dr. habil.sc.ing. in 1997. Since 1998, she has been aProfessor at the Latvia University of Agriculture. Scientific directions are studies of the novel and environmentally friendly biodegradable food packaging material application for food packaging technologies. She is the author of 190 scientific articles and 4 books. She is an EC expert in Brussels, reg. NoEE19981A03785. She has participated in the EU financed International projects EcoPac, QLRT-2001-01823 and PackTeck, N G1RTC-CT-2002-05068.

E-mail: lija.dukalska@1lu.lv

Liga Skudra, Dr. sc. ing., Professor. She was born in Latvia, Gulbene, in 1942. She received her Doctoral, Degree in Biotechnology in 1993. Since 2001, she has been a Professor at the Latvia University of Agriculture, Faculty of Food Technology, and Department of Food Technology. Main scientific directions are food safety, food microbiology and milk whey processing. She is the author of about 125 scientific articles.

E-mail: liga.skudra@1lu.1v

\section{Ingrīda Augšpole, Tatjana Rakčejeva, Lija Dukalskka, Līga Skudra. Kvalitātes nodrošināšana ar ozonētu ūdeni apstrādātiem rīvētiem} burkāniem uzglabāšanas laikā

Pētījuma mērḳis bija novērtēt kvalitātes izmainas svaigos rīvētos burkānos, kas tika apstrādāti $(60 \pm 1) \mathrm{s}$ ar 2 ppm ozonētu krāna ūdeni uzglabāšanas laikā. Ar ozonētu ūdeni apstrādātie burkāni bija iepakoti dažādos biologíski sadalāmos (biodegradējamos) hermētiski noslēgtos iepakojuma materiālos: NatureFlex ${ }^{T M} N V S, B I O-P L A$ trauciņos, BOPP Propafilm ${ }^{T M} P 2 G A F$ plēvē ar augstām barjerīpašībām un uzglabāti lesusskapī $(+4 \pm 1)^{\circ} \mathrm{C}$ temperatūrā desmit dienas. Izmantojot standarta metodes, rīvētu burkānu paraugos tika analizēti: kopējais karotinoīdu, $\beta$-karotīna un kopējais fenolu saturs, antioksidantu aktivitāte, šḳistošās sausnas saturs, masas zudumi iepakojumā, $\mathrm{CO}_{2}$ un $\mathrm{O}_{2}$ saturs iepakojumā, mitrums, pH, stingrība, krāsa un mikrobiologiskie parametri (zarnu grupas baktērijas, raugi un pelējumi, kā arī mezofìli aerobie un fakultatīvi anaerobie mikroorganismi). Paraugu testēšana tika veikta pirms iepakošanas un uzglabāššanas laikā. Šajā pētījumā tika pierādīts, ka ar ozonētu ūdeni apstrādātos rīvētos burkānos ir iespējams saglabāt atbilstošus kvalitātes rādītājus. Tā rezultātā rīvētu burkānu derīguma termiņu, tos apstrādājot ar ozonētu ūdeni, var paildzināt līdz desmit dienām, taču neapstrādātus rīvētus burkānus var uzglabāt līdz piecām dienām. Pētījumā konstatēja, ka ozonētam ūdenim bija būtiska ietekme uz antiradikālo aktivitāti, šḳ̄stošās sausnas sastāvu, stingrību un mikrobioloğiskajiem 
parametriem pētītajos burkānu paraugos. Savukārt uz $\beta$-karotīnu, kopējo karotinoīdu, kopējo fenolu un pH saturu būtiskas izmaiṇas nenovēroja. Pētījumā pierādījās, ka iepakojuma materiālam bija būtiska ietekme uz burkānu kvalitātes rādītājiem uzglabāšanas laikā. Jāatzīmēe ka BIO-PLA trauciṇi bija visvairāk piemērotais iepakojums rīvētu burkānu uzglabāšanai, salīdzinot ar citiem pētījumā lietotajiem iepakojuma materiāliem.

Ингрида Аугшполе, Татяна Ракчеева, Лия Дукальска, Лига Скудра. Обеспечение качества тёртой моркови, обработанной озонированной водой во время хранения

Целью данного исследования являлся анализ качества тёртой моркови, обработанной озонированной проточной водой при концентрации 2ппм в течение $(60 \pm 1)$ сек. в процессе хранения. Обработанные образцы моркови были упакованы в разные материалы (герметично закрытые полимерной плёнкой BOPP Propafilm ${ }^{\mathrm{TM}}$ P2GAF контейнеры, на базе целлюлозы, изготовленной биодеградируемой плёнкой NatureFlex NVS и Polilactid BIO-PLA) и хранились при температуре $+4 \pm 1^{\circ} \mathrm{C}$ в течение десяти дней. Следующие параметры качества были проанализированы с использованием стандартных методов: общее количество каротиноидов и $\beta$-каротин, общий состав фенольных соединений, антирадикальная активность, растворимое сухое вещество, уменьшение массы, влажность, $\mathrm{pH}$, жёсткость, цвет, состав $\mathrm{CO}_{2}$ и $\mathrm{O}_{2}$ газов, а также микробиологические параметры. Анализ образцов проводился перед упаковкой и в процессе хранения. В течение данных исследований было доказано, что химический состав тёртой моркови возможно сохранить в процессе хранения путём обработки моркови озонированной водой; в результате срок годности тёртой моркови можно продлить до десяти дней, срок годности необработанной моркови - 5 дней. Также было установлено, что озонированная вода имеет существенное влияние на антирадикальную активность образцов, состав растворимого сухого вещества, мягкость и на микробиологические параметры свежей тёртой моркови; в свою очередь незначительное влияние выявлено на $\beta$-каротин, изменения цвета и состав фенольных соединений, каротинов, рН. Было доказано, что в процессе исследований тестируемые упаковочные материалы не имели значимого влияния на качество моркови в процессе хранения. Необходимо заметить, что материал Polilactid BIOPLA всё же больше подходит для упаковки при хранении тёртой моркови, чем остальные тестируемые упаковочные материалы. 